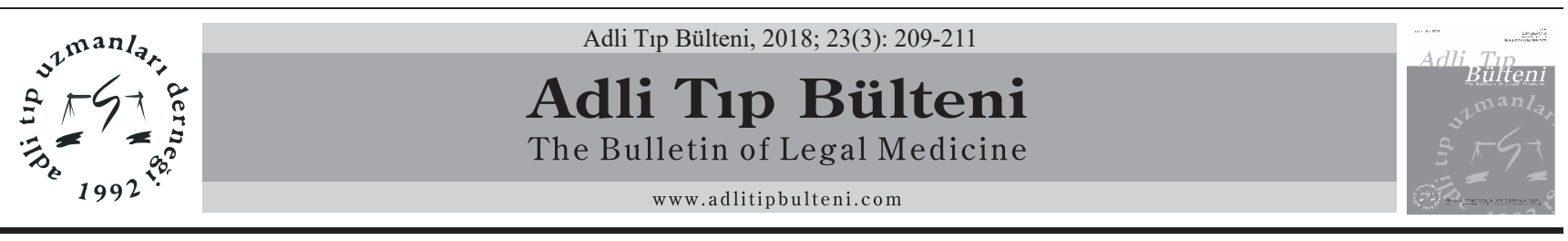

OLGU SUNUMLARI

doi: $10.17986 / \mathrm{blm} .2018345611$

\title{
A Case of Burn Related to Over-Heating of The Cell Phone Battery
}

\section{Cep Telefonu Bataryasının Isınmasına Bağlı Yanık Olgusu}

\author{
Fatmagül Aslan', Hacer Yaşar Teke ${ }^{2}$ \\ ${ }^{1}$ Health Sciences University, Antalya Training and Research Hospital, Clinic of Forensic Medicine, Antalya \\ ${ }^{2}$ Ordu University Medical Faculty, Department of Forensic Medicine, Ordu
}

\begin{abstract}
Contemporary communication tools are rather advanced tools, and cell phones have become indispensable parts of our daily lives. The purpose of this case report is to draw attention to new types of forensic cases that could develop in parallel with the advancement of technology and their consequences.

35 -year-old male's cell phone battery warmed up and burned his left hand, $2 \times 2 \mathrm{~cm}$ sized 2 nd degree burn wound with a $1 \times 1 \mathrm{~cm}$ bulb area in the middle was found on the left hand palm thenar area.

Today, mobile phone technology is the most advanced form of mobile communication in communication technologies. In our country and in the world there is a need for detailed studies dealing with health, communication, social, economic and legal aspects.

Keywords: Cell Phone; Battery; Burn; Accident.
\end{abstract}

\section{Özet}

Günümüzde iletişim araçları oldukça gelişmiş olup cep telefonları günlük yaşantımızın ayrılmaz bir parçası durumuna gelmiştir. $\mathrm{Bu}$ olgu sunumunun amacı teknolojinin ilerlemesi ve sonuçlarına paralel olarak gelişebilecek yeni adli olgu tiplerine dikkat çekmektir.

35 yaşında erkek olgunun cep telefonu bataryası isınıp sol elini yakmış ve sol el avuç içi tenar alanda $2 \times 2 \mathrm{~cm}$ boyutunda 2 . derece yanık yarası ve ortasında patlamış $1 \mathrm{x} 1 \mathrm{~cm}$ bül alanı saptanmıştır.

Günümüzde cep telefonu teknolojisi, iletişim teknolojileri içinde en fazla gelişme gösteren mobil iletişim biçimidir. Ülkemizde ve dünyada bu alanda yapılacak ayrıntılı ve konuyu sağlık, iletişim, sosyal, ekonomik ve hukuki boyutları ile ele alacak çalışmalara ihtiyaç bulunmaktadır.

Anahtar Kelimeler: Cep Telefonu; Batarya; Yanık; Kaza.

\section{Introduction}

Contemporary communication tools are rather advanced tools, and cell phones have become indispensable parts of our daily lives. Issues included being exposed to radiation, improper use by children (negative effects such as creating dependence, visual impairment, etc.), communication forms being affected negatively, being vulnerable to unknown risk and accidents and similar are now under discussion in relation with cell phones.

There are very few published medical literatures on cell phone-related burns (1-3). Only one of the seven cases in the literature was found to have first degree burns (4) and others were second and third degree burn cases (3).

The purpose of this case report is to draw attention to new types of forensic cases that could develop in paral-

Corresponding Author: Assoc. Prof. Dr. Hacer Yaşar Teke Ordu University Medical Faculty, Department of Forensic Medicine, Ordu

E-mail: hacer.hgulderen2004@gmail.com

Arrived: 12.02.2018 Revised: 25.04.2018 Accepted: 24.05.2018 lel with the advancement of technology and their consequences.

\section{Case}

A 35-year-old man complained of the fact that his cell phone battery warmed up and burned his left hand with testimony at the Police Headquarters. This individual had stated that he felt pain in his left palm when looking for an information on his cell phone within seconds, then when he turned the back of the phone, he saw that the back-plastic cover of the phone had melted and there were bulges on the cover, burns had formed in his palm, then he left the phone on the floor and left the place taking his child with him (Photograph 1). He had continued in his statement that the charging cable of the phone was not connected during the incident, and that the phone was still hot when he checked after 3 to 4 hours. In his forensic examination, a $2^{\text {nd }}$ degree burn wound $2 \times 2 \mathrm{~cm}$ in size with a torn bullous area in the center $1 \times 1 \mathrm{~cm}$ in size were seen in the thenar area his left palm consistently with his statement (Photograph 2). 


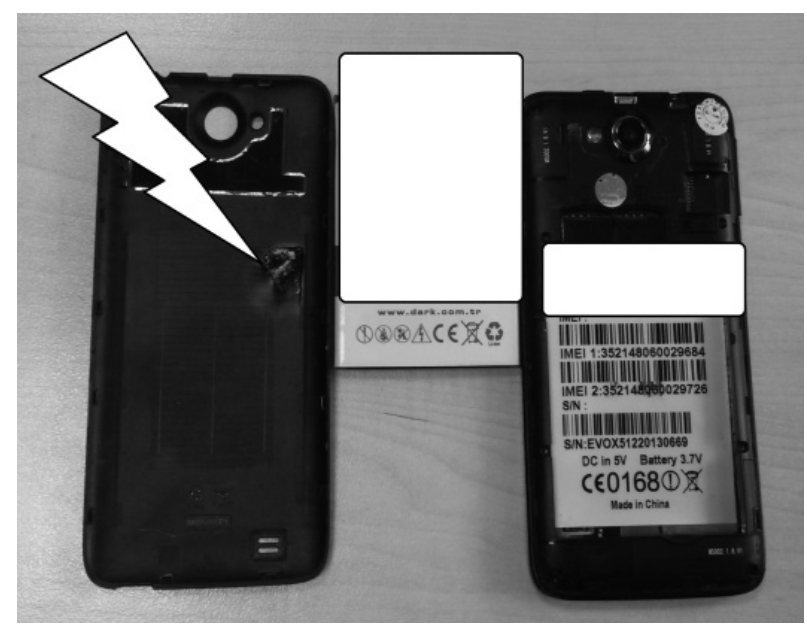

Photograph 1: The plastic part that melts and bulges due to the warming of the mobile phone battery is shown.

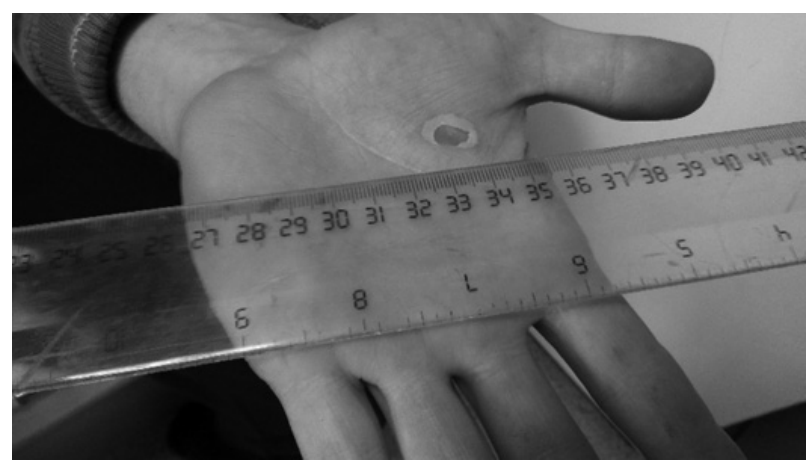

Photograph 2: Burn related to the over-heating of the cellphone in patient's hand

Melting and deformation was found on the back side and upper right corner of the cell phone brought for examination by the patient that overlapped with the lesion in the patient's palm.

Examination of the judicial file revealed that the cell phone in point was manufactured in the Far East. Furthermore, the imported cell phone was being marketed by a domestic firm. Our case preferred settlement with this firm during the course of the lawsuit.

\section{Discussion and Conclusion}

The cell phone technologies, appear as one of the mobile communication form that had developed the most among all the communication technologies in our times (5). As stated by Maslow, products mean more than their functional needs for consumers nowadays (6).

Based on the data of the Turkish Statistics Institute for 2015, cell phone ownership in households in Turkey is around $96.8 \%(7)$. Some studies are attracting attention to the addiction for cell phones, which is now more fre- quent than alcohol or substance addiction (8). According to TÜİK data, the ratio of number of mobile subscribers to population of age 15 and over 15 , reached to 100,34 in 2006 while it was 31,71 in 2000 (7).

With the "Communiqué on Electronic Commerce Information System and Notification Obligations" which was published in the Official Gazette in August 2017, the entry and authenticity of mobile phones in our country were partially controlled (9).

This regulation covers only consumers who purchase their $2^{\text {nd }}$ cell phones from abroad, and it does not involve serious enforcements for firms who trade cell phones. While this legal regulation and following implementation are partially effective, they do not affect the ownership of cell phones, which is already high, and provides only tax supervision and control. We have the opinion that control and health warnings are required in relation with frequency and way of use and use by children. Furthermore, date on limiting of accidents related to the device by being/not being the product and original one are limited.

It has been reported in one study that mobile phones interact with some equipment in surgical areas cause wrong results $(10,11)$. It has been stated in similar studies that cell phones should not be used at distances to such equipment closer than 2 to 3 meters in order to avoid adverse electromagnetic effects $(10,11)$. Karabağlı and colleagues presented the burns of a 16-year-old girl related to the explosion of a cell phone that they did not have access to sufficient data on cell phone accidents in their literature review (12).

We advocate that detailed studies in this area are required in Turkey and in the world to handle this issue with health, communication, social and economic aspects, and furthermore, strict legal sanctions must be in place in relation with importing firms.

\section{References}

1. Ben D, Ma B, Liu L, Xia Z, Zhang W, Liu F. Unusual burns with combined injuries caused by mobile phone explosion: watch out for the mini-bomb! J Burn Care Res 2009;30:1048 DOI: https://doi.org/10.1097/BCR.0b013e3181bfb8c0

2. Rose AM, Raraty C, Hassan Z. Full thickness burn caused by lithium ion battery in mobile phone. Burns 2009;35:S23 DOI: https://doi.org/10.1016/j.burns.2009.06.092

3. Mankowski PJ, Kanevsky J, Bakirtzian P, Cugno S. Cellular phone collateral damage: A review of burns associated with lithium battery powered mobile devices. Burns, 2016; e61e64 DOI: https://doi.org/10.1016/j.burns.2015.10.012

4. Sharma S, Majumdar A. Superficial burn to the ear caused by a mobile phone. Br J Oral Maxillofac Surg 2009;47:2445. DOI: https://doi.org/10.1016/j.bjoms.2008.09.005 
5. Aydoğdu İ, Karaaslan İA, Budak L. Research on the Use of Mobile Phone Features by University Students and Its Impact on Their Communication Practices in Everyday Life. Journal of Yasar University 2012;26(7):4548 - 4555.

6. Maslow A.H. (1954). Motivation and Personality. Prentice Hall, Upper Saddle River, New Jersey.

7. Türkiye İstatistik Kurumu Web Sitesi. URL: http://www. tuik.gov.tr Erişim Tarihi: 24.05.2017.

8. Güler A. Tabacco, alcohol, substance using and effect of socio-economic level among Ege University preparatory class students. Doctoral dissertation. Ege University, 2008.

9. Elektronik Ticaret Bilgi Sistemi ve Bildirim Yükümlülükleri Hakkında Tebliğ. Resmi gazete: 11.08.2017, say1: 30151 URL: http://www.resmigazete.gov.tr/eskiler/2017/08/20170811-7.htm Erişim Tarihi: 29.04.2018.

10. Potokar T, MacKenzie Ross AD, Clewer G, Dickson WA. Mobile phones - a potential fire hazard? Burns 2003;29:493-4. DOI: https://doi.org/10.1016/S03054179(03)00051-2

11. Klein AA, Djaiani N. Mobile phones in the hospital-past, present and future. Anaesthesia 2003;58:353-7. DOI: https://doi.org/10.1046/j.1365-2044.2003.03079.x

12. Karabağlı Y, Köse AA, Çetin C. Partial thickness burns caused by a spontaneously exploding mobile phone. Burns,2006; 32:922-924 DOI: https://doi.org/10.1016/j. burns.2006.03.009 